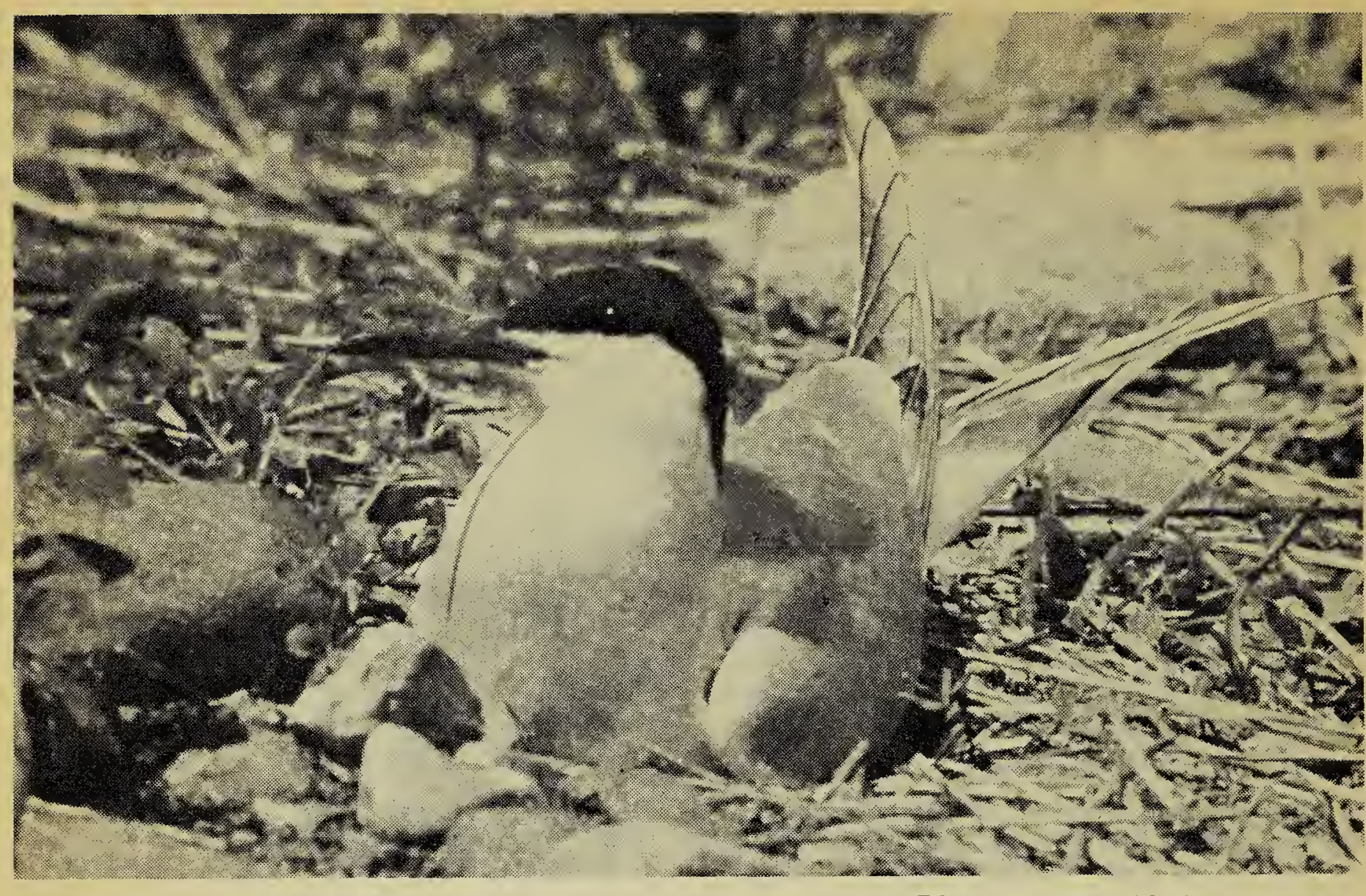

COMMON TERN

Photo by Kay Hodges, Calgary

\title{
A Possible Least Tern in Saskatchewan
}

by Frank Brazier, Regina

On the evening of May 26, 1957, in bright sunshine, Elimer Fox and I stood on the railway right-of-way crossing an extensive flooded field just south of Regina. Overhead the air was full of Common and Black Terns. Elmer suddenly called to me: "See that little white tern-what is it?" We both got our glasses on the bird in question as it wheeled among its fellows-a small white tern, with a black cap, much smaller than the Common Terns and about the size of the Black Terns. I have a distinct impression that the legs were lightcoloured, but we knew nothing then of the field marks of the Leasit Tern (Sterna albifrons) so did not look for the white forehead and the yellow bill and legs. In the few moments when we could see the bird clearly before it swung westwards into the sun and was lost forever, we obtained the general impression of a small white tern with a black cap, about the size of a Black Tern.

Least Terns penetrate far up the Mississippi Valley so it wasn't unreasonably far from the northern limit of its range. For two or three days previously we had had strong southerly winds. A tremendous river of air pouring at greait speed northwards had flooded the prairies and the tern could have come this far simply riding the gale.

\section{IN DEFENCE OF CROWS}

Occasionally an item comes to our attenition defending the muchmaligned Crow. In this vein Ernest J. White of Dunrea, Manitoba, wrote recently to the Blue Jay about the great flocks of crows which he watched in the fields and pastures during the month of August this year. When he looked at them closely he could see that they were catching grasshoppers. The crows were also spoitted many times on the summerfallow, also catching grasshoppers. This service to the farmers, Mr. White feels, far outweighs any damage the crows may do. We remember Doug Gilroy describing the great flocks of crows that moved through the Regina area last year and setitled on the swaths-but not to eat grain. They were discovered to be hunting grasshoppers and crickets. 